\title{
Demand Analysis and Planning Research on the Construction of the Power Equipment Logistics Park in a Company
}

\author{
Jianhua Chen \\ Hunan Vocational College of Modern Logistics \\ Changsha, Hunan, China 410131
}

\author{
Shijun Yuan* \\ Hunan Vocational College of Modern Logistics \\ Changsha, Hunan, China 410131 \\ *Corresponding Author
}

\begin{abstract}
Based on the analysis of the necessity and feasibility of the construction of power equipment logistics park of A Company in HY City, this paper mainly analyzes and forecasts the logistics functional requirements and land use scale of the construction of Logistics Park, and studies the general layout plan of logistics parks according to functional requirements and land conditions.
\end{abstract}

\section{Keywords-logistics park; demand analysis; planning}

\section{INTRODUCTION}

In recent years, in order to obtain the advantages in the fierce market competition, the A Company has formulated a strategy that develops the producing-service industry and steps into the field of logistics, finished product service, trade, finance and e-commerce. The construction of A Company's power equipment logistics park is an important measure for the development to the production service industry. This park is a modern logistics park which is mainly based on the power transmission and transformation equipment logistics and the related trade, finance, e-commerce, emergency services, training and technology research and development, and is supplemented by third-party logistics for other industries. This park has become a productive service base for power transmission and transformation which serves the country and faces the world.

\section{ANALYSIS OF NECESSITY OF PROJECT CONSTRUCTION}

\section{A. The Needs of Promoting the Transformation and Upgrading of the Power Transmission and Transformation Manufacturing Industry}

1) Important strategic measures of A Company's developing in the direction of producing-service industry

A Company has become one of the most important core manufacturing bases for Ultra-high voltage transformer and reactor in China and even in the world. The output of a single transformer factory has ranked first in the world. The company will cooperate with HY municipal government to build the top three world industrial bases, namely, world-class high-end power transmission and transformation equipment manufacturing base, state-level power transmission and transformation supporting industry base and large international equipment logistics industry base.

2) The needs of promoting the development of $A$ Company's supporting industry and logistics industry

In June, 2012, A Company invested and established the wholly-owned subsidiaries, Hunan International Equipment Logistics Trade Co., Ltd of A Company. The International Equipment Logistics Co., Ltd is doing every effort to build a domestic and international big commercial and large logistics network system, at present, the system has begun to take shape and form. However, due to lack of its own logistics base, the development of bulk materials, such as steel, transformer oil, copper and coal, has been greatly restricted and inconvenient.

B. The Needs of Promoting the Joint Development of the Two Industries, Manufacturing Industry and Logistics Industry, in HY City

1) Promote the development of HY City's manufacturing industry

Internationally, the proportion of logistics costs to GDP is usually regarded as an important index to measure the efficiency and benefit of logistics. After the implementation of modern logistics, this index in the developed countries and regions has been controlled at about 10\% (10.5\% in the United States, $11.4 \%$ in Japan, $13.1 \%$ in Taiwan, $13.9 \%$ in Singapore, and $13.7 \%$ in Hong Kong). The proportion of logistics costs to GDP in the whole HY City is nearly $20 \%$, and the logistics cost is two times as much as those of developed countries. The backward logistics industry in HY City has become a bottleneck restricting the development of production and manufacturing industry. The creation and cultivation of the professional third-party and fourth-party logistics can deepen the management on the enterprise's supply chain, optimize the business process, reduce the enterprise's supply chain costs, enhance the enterprise's competitive capability, and promote the development of the manufacturing industry in the whole city.

2) The needs of promoting $H Y$ to undertake industrial transfer

By 2020, the southern Hunan will have become an important platform for undertaking the east area and radiating 
the central region, as well as a new fulcrum for boosting the development of the central region. The overall economic strength of the demonstration area has been greatly improved, and a number of characteristic and intensive industrial parks have been formed. The patterns complement each other in advantages and form integrative development with the Pearl River Delta and other areas is basically established. This area will have a sound social security and beautiful ecological environment, and people will live a rich life. The implementation of the plan will forcefully facilitate the enterprises in Yangtze River Delta and Pearl River Delta to transfer their industries to the HY area. The project site is a national key industrial park jointly built by People's Government of Hunan Province and Shenzhen Municipal People's Government to strengthen regional economic cooperation and effectively undertake the industrial transfer in Shenzhen and other Pearl River Delta regions. It is objectively required to construct a big market system based on the modern logistics. However, the international equipment logistics park relying on A Company is close to Baisazhou industrial park, and has the unique advantages in the capital, technology, personnel, management, brand and resource, which can better promote the transfer of industries.

\section{The Needs of Promoting Traditional Logistics to Transfer to Modern Professional Logistics}

Over the years, although the logistics industry in HY City has developed, it still stays in the traditional and spontaneous logistics stage. Whether the organizational structure and operation mode or economic and social benefits, it still has a great distance from the requirements and goals of modern logistics. The main problems include the traditional logistics mode, low linkage level between manufacturing and logistics industry, low level of logistics informationization, backward business and trade logistics, high proportion of self run business and so on. It is urgent to build a large modern comprehensive logistics park. Through the intensive effect, modern technology and infrastructure, high-quality service level and networked operation, the park will be developed into an indispensable modern logistics node and platform connecting to the Pearl River Delta and radiating the central region.

\section{PROJECT FEASIBILITY ANALYSIS}

\section{A. Convenient Traffic Condition}

The logistics park is adjacent to the Baishazhou industrial area, and a large number of industrial backbone enterprises are distributed at the north end of the park. The park has the unique advantages of developing the industry, with convenient traffic, closing to the central urban area; there are a number of connected high-grade highways and expressway. The urban trunk road has extended to the park. The railway station where the Beijing-Guangzhou railway meets the Hunan-Guizhou railway is $6 \mathrm{~km}$ away from the park. The Guangzhou-Wuhan high-speed railway passes by the east of the park, with HunanGuangxi railway and south bus station adjacent to the park; Dingjiaqiao, a one-kiloton pier, which ranks second in single lifting supporting capacity in the inland river, is only $2 \mathrm{~km}$ away from the park, The new airport under construction is located in the south of the park. The park has been equipped with water, gas, communications, broadband, etc., and the enterprise can open them for use upon the entry of the park.

\section{B. The Advantages of Leading Enterprises in Power Transmission and Transformation Industry Clusters Have Formed}

A Company has built a world-class high-end power transmission and transformation equipment manufacturing base and a state-level power transmission and transformation supporting industry base. Depending on the advantages of leading enterprises in power transmission and transformation industry clusters, after nearly 2 years of development, International Equipment Logistics Trade Co., Ltd of A Company has achieved good results in power transmission and transformation material and main parts and accessories, power transmission and transformation equipment, non-ferrous metal, transformer oil, steel, coal trade, logistics finance and other fields. The Company has the unique advantages in capital, technology, resource and brand, and the existing business of Hunan International Equipment Logistics Park of A Company can effectively support the operation of the logistics park.

\section{Good Policy Environment}

HY municipal people's government has signed the Strategic Cooperation Frame Agreement on Deepening the Cooperation of Xin-Xiang and Building Three Top Industrial Bases in HY City with A Company Limited, and the agreement has given multiple supports to the policies such as land price, tax revenue, preferential policies for fiscal subsidies, talent introduction and so on.

\section{LOGISTICS DEMAND ANALYSIS AND LAND USE FORECAST}

\section{A. Analysis of Logistics Demand}

In recent years, A Company Group has quickened the development in the direction of production servicing business and proposed to build a modern production service base based on logistics in HY City, which will radiate the entire southern region and face the world and focus on the logistics.

At present, the total logistics volume of raw materials and spare parts purchased and the delivered finished products exceeds 400 thousand tons, while the total logistics volume of the whole Group in the south exceeds 1 million tons. In this project, the annual logistics demand for non-ferrous metals, semi-finished products and finished products in the whole Mid-South Region will reach 20 million tons, and at the same time, the demand for logistics, trade, finance, e-commerce, and information services has increased year by year. The Company urgently needs to build a modern logistics park to optimize and integrate these businesses. This will be not only beneficial to the industrial structure adjustment of A Company, but also of great significance to accelerating the development of modern service industry and the adjustment of industrial structure in HY City, stimulating the linkage development of manufacturing and logistics industries in HY City and strengthening the construction of industrial transfer demonstration area in South Hunan. 


\section{B. Forecast on the Demand of Project's Total Floor Space}

There are many factors affecting the planning and construction scale of logistics park, therefore, we will determine the overall construction scale of the logistics park starting form the total logistics volume in the area covered by this project.

In the regional logistics planning, if the number of working days is 365 per year, the total construction scale of the logistics park is as follows:

\section{$\mathrm{S}=\mathrm{L}$ I1I2a $/ 365$}

\section{$\mathrm{S}=\mathrm{L}$ I1I $2 \mathrm{a} / 365$}

In the formula: $\mathrm{S}$ is the total construction area $\left(104 \mathrm{~m}^{2}\right)$ of the logistics park; $\mathrm{L}$ is the total logistics volume (104t) of the whole society in the year of forecasting and planning goal; I1 is the proportion of third-party logistics (3PL) market to the whole society logistics market in the year of planning goal; I2 is the proportion of 3PL's workload through the logistics park to all the logistics workload of the 3PL in the year of planning goal; $a$ is the parameter of unit production capacity land-use $\left(\mathrm{m}^{2} / \mathrm{t}\right)$.

Considering the geographical location and economic environment of the project, combined with the possible development trend in the next 5 years, the demand for the scale of the logistics park is predicted as follows:

\section{$\mathrm{S}=\mathrm{L}$ I1I $2 \mathrm{a} / 365$}

\section{$\mathrm{S}=\mathrm{L} \mathrm{I} 1 \mathrm{I} 2 \mathrm{a} / 365$}

Taking $\mathrm{I} 1=50 \%, \mathrm{I} 2=65 \%, \mathrm{a}=40$, the following can be obtained through the calculation:

\section{$\mathrm{S}=2000 * 50 \% * 65 \% * 40 / 365 \approx 710,000 \mathrm{~m} \approx 1000 \mathrm{mu}$}

\section{CONSTRUCTION CONTENT IN THE PARK}

This project is divided into the following eight functional areas: comprehensive office service area, storage service area (southern power transmission and transformation materials and accessories supply center, nonferrous metal futures delivery storage, and transformer oil and lubricant oil storage and distribution area), transportation service area, e-commerce and logistics information service area, display transaction service area (A Company's international equipment exhibition trading center, transformer oil and lubricant oil display trading center, and southern power transmission materials and main parts display trading center), modern city distribution service area, power transmission and transformation equipment emergency service area, and supporting life service area.

Hunan International Equipment Logistics Park project of A Company has been constructed in two phases, mainly including eight functional areas, and the general layout is as follows:

\section{A. Comprehensive Office Service Area}

Located in the southeast of the project base, this area provides a comprehensive administrative office service for the enterprises. This area is tend to construct one logistics headquarters building and one comprehensive service building, with a total floor area of 30 thousand square meters, of which the floor area of the logistics headquarters building and the comprehensive service building is 20 thousand square meters and 10 thousand square meters respectively.

\section{B. Storage Service Area}

This area is tend to construct three storage service areas, namely, southern power transmission and transformation materials and accessories supply center, nonferrous metal futures delivery storage, and transformer oil and lubricant oil storage and distribution area.

\section{1) Nonferrous metal futures delivery storage center}

Located in the northwest corner of the project base, this area provides the online business services which unify commodities information, release and query of supply and demand information, exchange and financing of standard/nonstandard warehouse receipt, two-way performance supervision of trading capital and delivery goods. The platform also includes warehouse receipt supermarket, warehouse receipt auctions, purchase and sales brokerage, online financing, industry information, quotations and other innovative services. This area has a total floor area of 40 thousand square meters.

2) Southern power transmission materials and main parts and accessories supply center

Located on the south side of nonferrous metal futures delivery storage in the project base, this area provides the business customers in southern power transmission and transformation industrial park with power transmission and transformation materials and main parts and accessories, such as, silicon steel, copper rods, casing pipe, switches, valves, coolers and so on. This area has a total floor area of 50 thousand square meters.

3) Transformer oil and lubricant oil storage and distribution center

This area is located on the south side of the power transmission materials and main parts and accessories supply center of south China in this project. With the help of primary sales agent in the South Central China and the sole agency in the Southeast Asia region of PetroChina transformer oil, the largest oil distributor and trader in the South China will be built by the Company. The products will be sold throughout the country and the Southeast Asian market, and the Company will provide services such as information consulting, oil filtering, oil storage, distribution and so on. 50 oil tanks with the capacity of 20 thousand tons will be built in this area, and its maximum oil storage capacity can reach 1 million tons, with a total floor area of 80 thousand square meters.

\section{Display Transaction Service Area}

This area is located in the northeast corner of the project base, and mainly used to build southern power transmission materials and main parts display trading center and A Company's international equipment exhibition trading center. The total floor area is 180 thousand square meters, of which the floor area of southern power transmission materials and main parts display trading center and A Company's 
international equipment exhibition trading center is 80 thousand square meters and 100 thousand square meters respectively. After the completion of the construction, about 100 equipment traders will be introduced.

\section{Transportation Service Area}

This area is located in the southeast corner of the project base, and mainly used to build LCL loading center, special line transport service center, special and general cargo vehicle parking lot, vehicle repairing workshop and so on, with a total floor area of 42.5 thousand square meters.

\section{E. E-Commerce and Logistics Information Service Area}

This area is located on the south side of comprehensive office service area of project base. One e-commerce and logistics information building will be built in this area, with a total floor area of 18 thousand square meters.

\section{F. Modern City Distribution Service Area}

This area is located in the east of southern power transmission and transformation materials and accessories storage. One distribution center will be built in this area, with a total floor area of 100 thousand square meters. Through the use of a sound logistics infrastructure and advanced logistics information platform, we can guide the relatively distributed storage enterprises and transport enterprises to concentrate on the logistics park, attract domestic and foreign circulation capital and chain enterprises into logistics park to conduct logistics and distribution business, and promote more thirdparty logistics to form professional distribution service providers in the field of urban fast-moving consumer goods, agricultural products and building materials, so as to ease the growing pressure of urban distribution and provide distribution efficiency.

\section{G. Power Transmission and Transformation Equipment Emergency Service Area}

This area is located at the southern end of the modern urban distribution service area of the project base, with a total floor area of 12 thousand square meters.

\section{H. Supporting Life Service Area}

This area is located in the southwest corner of the park, and mainly is equipped with the living support facilities, such as, shifting dormitories, driver hotels, canteens, and so on, with a total floor area of 13 thousand square meters.

\section{CONCLUSION}

The construction of modern large-scale comprehensive logistics parks is an urgent need to promote the development of China's power transmission and transformation equipment industry, as well as promoting the economic and social development of HY City. Moreover, the construction of this project has a strong feasibility: the selected site has excellent traffic location advantages; the land has a strong resource cost advantage; the investment has considerable comprehensive benefit advantages; the project construction unit has strong comprehensive advantages in capital, technology, market, talent and so on.

\section{REFERENCES}

[1] Wan Shunjiang. Discussion on the Planning and Construction for Logistics Park [J]. China Logistics \& Purchasing. 2014(10)

[2] Wang Le. Research on Planning of Urban Trading Logistics Park [D]. Lanzhou Jiaotong University 2015

[3] Wang Wen. Construction and Research of Architectural Function of Modern Logistics Park [D]. Hunan University 2014

[4] Zhang Lanyi. Research on Key Issues of Urban Logistics Park Planning [D]. Fujian Agriculture and Forestry University 2012 